\title{
MEMPERKUAT POTENSI LOKAL GUNA MENINGKATKAN DAYA SAING DI KOTA TERNATE
}

\author{
Linda Umasugi \\ Staf Pengajar FAPERTA UMMU-Ternate,e-mail: linda.umasugi@yahoo.com
}

\begin{abstract}
ABSTRAK
Di dalam mewujudkan Visi pembangunan Dinas Perindustrian Dan Perdagangan Kota Ternate adalah : "Mewujudkan Perindustrian dan Perdagangan Sebagai Penggerak Perekonomian Rakyat yang Berbasis Pada Sumber Daya Lokal”. Untuk mewujudkannya maka perlu ditetapkan Misi Pembangunan Perindustrian dan Perdagangan sebagai berikut :1. Meningkatkan kwalitas sumber daya aparatur sebagai penyelenggara pembangunan di sektor Industri dan Perdagangan;2. Peningkatan pembinaan Industri Kecil dan Menengah dengan mengembangkan potensi Sumber Daya Alam Lokal;3. Memperkuat Basis Sumber Daya Alam dan Sumber Daya Manusia secara optimal, yang Produktif mandiri dan mampu berdaya saing;4. Menciptakan pendalaman struktur industri dan pelestarian Kerajinan Tradisional Daerah dan;5. Mewujudkan pembinaan terhadap pelaku Industri dan Perdagangan dan meningkatkan penyediaan barang dan jasa untuk kebutuhan masyarakat. Untuk Kota Ternate pertumbuhan ekonomi ditopang dengan potensi lokal yaitu 10-15\% yang ditunjang oleh adanya Home industri. Di Kota Ternate sendiri home industri berskala kecil ada 780 unit, tenaga kerja yang terserap 2.718 orang, jika dibandingkan dengan Perdagangan yang ada di Ternate 839 unit, terserapnya tenaga kerja hanya 1.011 orang, jika dibandingkan antara industri dan perdagangan ada perbedaan yang mencolok dalam perkembangannya hal ini dikarenakan industri di Kota Ternate sendiri perkembangannya berjalan lambat dikarenakan dipengaruhi oleh budaya kerja, karakter setiap individu, budaya persepsi dan manajemen produksi yang masih lemah. Usaha yang telah dilakukan oleh Dinas Perdagangan dan Industri terkait dengan manajemen produksi dengan memberikan pelatihan-pelatihan manajemen dan mengusahakan desa percontohan usaha seperti mengembangkan usaha kursi rotan dan kain tenun khas Maluku Utara namun sampai sekarang terbentur oleh pemasaran. Dan untuk home industri makanan khas kendala yang di hadapi adalah terbentur biaya di dalam soal labelisasi dan sertifikasi produk.
\end{abstract}

\section{Kata Kunci: Potensi Lokal, Daya Saing, Home Industri}

\section{PENDAHULUAN}

\subsection{Latar Belakang}

Berdasarkan Peraturan Pemerintah Daerah Kota Ternate No. 15 taun 2007 tentang Organisasi Dinas-Dinas Daerah Kota Ternate, Dinas Perindustrian dan Perdagangan Kota Ternate berkedudukan sebagai salah satu unsure pelaksana Pemerintah Daerah yang dipimpin oleh seorang Kepala Dinas yang berada di bawah setingkat dan bertanggung jawab melalui Sekretariat Daerah, kepada Walikota Ternate.

Dinas Perindustrian dan Perdagangan Kota Ternate sebagaiaman ketentuan Peraturan Walikota Ternate No. 15 tahun 2007 tentang
Organisasi Dinas-Dinas Kota Ternate mempunyai wewenang otonomi daerah dalam rangka pelaksanaan tugas desentralisasi di bidang Perindustrian dan Perdagangan.

Dalam melaksanakan tugas sebagaimana dimaksud, Dinas Perindustrian dan Perdagangan Kota Ternate, mempunyai fungsi : a. Pelaksanaan kebijakan tekhnis dibidang Perindustrian dan Perdagangan; b. Pemberian perijinan dan pelaksanaan pelayanan dibidang Perindustrian dan Perdagangan; c. Pelaksanaan urusan Sekretaris dan Rumah Tangga Dinas.

Perekonomian rakyat menegaskan bahwa, industri dan perdagangan telah memiliki 
kemampuan untuk tumbuh dan berperan secara signifikan dalam pembangunan ekonomi.Peran tersebut dapat diwujudkan melalui pemberdayaan industri dan dagang kecil-menengah yang banyak digeluti oleh rakyat maupun dalam kaitannya dengan pemberdayaan usaha rakyat di sektor ekonomi lainnya

\subsection{Permasalahan}

Dari uraian tersebut diatas maka dapat dirumuskan salah satu masalah yang dihadapi dalam pengembangan industri kecil-menengah adalah keterbatasan pengetahuan dan ketrampilan para pengusaha/perajin baik pada aspek teknologi maupun manajerial.

\subsection{Tujuan}

Penulisan ini bertujuan untuk membahas masalah yang dihadapi dalam pengembangan industri kecil-menengah dalam memperkuat potensi lokal guna meningkatkan daya saing di kota Ternate.

\section{PEMBAHASAN}

Industri sebagai penggerak perekonomian rakyat mengandung pengertian bahwa tumbuh dan berkembangnya dunia industri akan mampu mengoptimalkan pemanfaatan sumber daya local yang tersedia. Sementara perdagangan sebagai penggerak perekonomian rakyat mengandung pengertian bahwa tumbuh dan berkembangnya Perdagangan dan Perindustrian, akan member kontribusi yang signifikan terhadap pengembangan dunia usaha dan sektor jasa, disamping memperlancar arus barang dan jasa untuk memenuhi kebutuhan masyarakat.

Industri dan Perdagangan yang berbasis pada sumber daya local mengandung makna bahwa proses industrialisasi dan perkembangan sektor perdagangan harus lebih diutamakan pada optimalisasi pemanfaatan sumber daya local, baik sumber daya alam maupun sumber daya manusia. Melalui pembangunan yang bermuara pada perwujudan industri dan perdagangan sebagai penggerak perekonomian rakyat serta basis pada sumber daya local, maka pembangunan industri dan perdagangan dalam satu system yang sinergis akan mampu mewujudkan tujuan dan sasaran pembangunan di bidang ekonomi sehingga dapat mendorong percepatan pencapaian Visi dan Misi Kota Ternate, sebagai Kota Budaya, Kota Perdagangan dan Kota Wisata serta Kota Pantai.

\subsection{Perencanaan Strategi}

Visi pembangunan Dinas Perindustrian Dan Perdagangan Kota Ternate adalah : "Mewujudkan Perindustrian dan Perdagangan Sebagai Penggerak Perekonomian Rakyat yang Berbasis Pada Sumber Daya Lokal". Untuk mewujudkan Visi pembangunan Perindustrian dan Perdagangan Kota Ternate, maka perlu ditetapkan Misi Pembangunan Perindustrian dan Perdagangan sebagai berikut : 1 . Meningkatkan kwalitas sumber daya aparatur sebagai penyelenggara pembangunandi sektor Industri dan Perdagangan; 2. Peningkatan pembinaan Industri Kecil dan Menengah dengan mengembangkan potensi Sumber Daya Alam Lokal; 3. Memperkuat Basis Sumber Daya Alam dan Sumber Daya Manusia secara optimal, yang Produktif mandiri dan mampu berdaya saing; 4. Menciptakan pendalaman struktur industri dan pelestarian Kerajinan Tradisional Daerah dan; 5. Mewujudkan pembinaan terhadap pelaku Industri dan Perdagangan dan meningkatkan penyediaan barang dan jasa untuk kebutuhan masyarakat.

\subsection{Program Operasional}

Untuk mengimplemantasikan strategi yang telahditetapkan, maka beberapa kegiatan pokok dan program pembangunan industri dan perdagangan adalah :

\subsubsection{Program Sektor Industri}

a. Program pengembangan Industri kecil dan Menengah. Termasuk didalamnya adalah industri rumah tangga seperti Pembuatan sirup pala, Tenunan kain khas, Kerajinan Rotan dan lain-lain (lihat Daftar Lampiran), dimana merupakan kelompok industri yang banyak diusahakan oleh masyarakat dengan memanfaatkan potensi-potensi sumber daya local yang tersedia. Upaya mengembangkan industri kecil-menengah termasuk industri rumah tangga dilaksanakan dengan mengembangkan jiwa kewirausahaan dan latihan yang lebih baik tekhnis maupun manajerial, magang/studi banding, bimbingan dan penyuluhan, promosi dan informasi, penyediaan sarana dan fasilitas usaha.

b. Program Teknologi Industri Kecil. Di samping kelemahan dan keterbatasan pad aaspek kualitas sumber daya manusia, pengusaha/perajin industri kecil-menengah termasuk industri kerajinan dan teknologi yang amat mennetukan dalam rangka meningkatkan kualitas dan kuantitas produksi maupun tingkat efisiensi dan produktifitas. Upaya meningkatkan kemampuan teknologi, 
akan dilakukan melalui bantuan peralatan dan sarana produksi, menyebarluaskan dan memberikan pelayanan informasi teknologi, rekayasa teknologi tepat guna (TTG), bantuan bahan baku dan bahan baku penolong, pengembangan mutu dan desain produksi

c. Program Penataan Struktur Industri. Iklim usaha yang konduktif merupakan prasyarat bagi kebutuhan berkembangnya usaha dimana masyarakat dapat terangsang untuk menanamkan investasinya dengan memanfaatkan berbgaia fasilitas dan kemudahan yang disediakan oleh pemerintah. Upaya penataan dan penciptaan iklim usaha dilakukan melalui pemberian kemudahan dibidang perizinan, fasilitas untuk memperoleh bantuan permodalan, pembentukan dan pengembangan kelembagaan usaha, peningkatan kerjasama instansi terkait, pengembangana kemitraan usaha dan penyediaan peraturan perundangundangan, Peraturan Daerah dan lain-lain yang berkiatan dengan pengaturan dan pengembangan usaha.

\subsubsection{Program Sektor Perdagangan}

a. Program Pengembangan Pasar. Program ini dilakukan secara tim dengan instansi terkait tentang pembentukan Tim pengawas dan Pengendalian Peredaran / Perdagangan Kebutuhan Pangan Kota Ternate. Pengawasan dilakukan 6 (enam) kaliyang dilakukan di pusat-pusat perbelanjaan menjelang Ramadhan, Lebaran, Natal dan Tahun baru. Salah satu tujuannya adalah untuk meningkatkan harkat dan martabat konsumen dengan cara menghindarkanya dari efek negative dalam mengkonsumsi dan atau pemakaian produk yang beredar di pasar.

b. Program Pengembangan Usaha dan Sarana Perdagangan. Program ini dilakukan dengan pengembangan kelembagaan usaha melalui pendataan dan penertiban gudang yang dilakukan 30 kali.

c. Program Pengawasan dan Pemantauan Kebutuhan Pokok Masyarakat. Program ini dilakukan untuk mengawasi peredaran barang yang beredar di masyarakat agar supaya barang tersebut tidak termasuk barang yang sudah kadarluarsa serta memantau perkembangan harga kebutuhan pokok masyarakat yang berkembang dalam perkembangan stock pada distribusi atau agen dan bertujuan untuk menjaga kestabilan harga pasar.

\subsection{Tingkat Daya Saing}

Tingkat daya saing komoditas ekspor suatu negara atau industri dapat dianalisis dalam berbagai macam metode. Tiga diantaranya adalah Revealed Comparative Advantage, Constant Market Share, dan Real Effective Exchange Rate.

\subsection{Daya Saing Global}

World Economic Forum (WEF) yang bermarkas di Geneva (Swiss) setiap tahun mengembangkan dan menerbitkan Global Competitiveness Index (GCI). GCI ini tidak mengukur tingkat daya saing ekspor secara eksplisit, tetapi tingkat daya saing suatu ekonomi atau negara. Namun demikian, indeks ini dapat digunakan sebagai salah satu alat untuk mengukur secara tidak langsung tingkat daya saing ekspor Indonesia.

GCI adalah suatu indeks gabungan dari sejumlah inidikator ekonomi yang telah teruji secara empiris memiliki suatu korelasi positif dengan pertumbuhan ekonomi (PDB) untuk jangka menengah dan panjang, dan berarti secara teoritis juga mempunyai suatu korelasi positif dengan kinerja atau tingkat daya saing ekspor.

\subsection{Potensi Lokal.}

Indonesia memiliki keunggulan komparatif (comparative advantage) dalamm banyak komoditas perkebunan. Sedikitnya 12 produk yang memiliki pangsa pasar di atas $30 \%$, antara lain meliputi komoditas seperti kelapa, kelapa sawit, karet alam, kakao, the, tembakau, kopi, lada dan lain-lain. Bahkan minyak atsiri dan rempah-rempah masing-masing menguasai $90 \%$ dan $80 \%$ pasar dunia.Hal ini tergambar dari tingkat produktif relative dan pangsa pasar produksi serta pangsa eksport di pasar internasional bila dibandingkan dengan Negara produsen utama lainnya.Untuk beberapa komoditas perkebunan utama seperti kelapa, kelapa sawit, karet dan kakao, Indonesia sangat berpeluang menjadi produsen dan eksportir terbesar di dunia. Hal tersebut ditunjukkan oleh pertumbuhan positif $(3,1 \%)$, dibandingkan dengan sektor lain yang mengalami pertumbuhan negative. Rata-rata eksport komoditas perkebunan per tahun tercatat sekitar 3,9\% milyar US\$ atau 47,44\% dari eksport sektor pertanian. Dengan kondisi diatas, tampak peranan sektor pertanian dan potensinya sebagai basis pemacu pemulihan ekonomi.Tidak hanya di kota-kota saja, tetapi juga di pedesaaan.Indonesia selama ini hanya mengandalkan kelimpahan sumberdaya alam dan tenaga kerja tak terdidik, tanpa 
berusaha untuk melakukan pengembangan terhadap SDA dan ketrampilan tenaga kerja.Masalah utama sektor pertanian di Indonesia adalah tidak diaplikasinya ilmu pengetahuan dan teknologi sehingga berakibat produktivitas yang sangat rendah, diversifikasi produk sangat minim, serta kualitas dan standar produk yang rendah. Akibatnya Indonesia dibanjiri oleh produk impor dan tidak mampu bersaing di pasar Internasional .Hines (200) menyatakan bahwa Lokalisme harus dilindungi dari globalisasi, karena globalisasi secara nyata menimbulkan dampak buruk terhadap masyrakat, keadilan dan lingkungan.

Untuk Kota Ternate pertumbuhan ekonomi ditopang dengan potensi local yaitu $10-15 \%$ yang ditunjang oleh adanya Home industri. Di Kota Ternate sendiri home industri berskala kecil ada 780 unit, tenaga kerja yang terserap 2.718 orang, jika dibandingkan dengan Perdagangan yang ada di Ternate 839 unit, terserapnya tenaga kerja hanya 1.011 orang,jika dibandingkan antara industri dan perdagangan ada perbedaan yang mencolok dalam perkembangannya hal ini dikarenakan industri di Kota Ternate sendiri perkembangannya berjalan lambat dikarenakan dipengaruhi oleh budaya kerja, karakter setiap individu, budaya persepsi dan manajemen produksi yang masih lemah.

Usaha yang telah dilakukan oleh Dinas Perdagangan dan Industri terkait dengan manajemen produksi dengan memberikan pelatihan-pelatihan manajemen dan mengusahakan desa percontohan usaha seperti mengembangkan usaha kursi rotan dan kain tenun khas Maluku Utara namun sampai sekarang terbentur oleh pemasaran.

\subsection{Daya Saing}

Prestasi perekonomian Indonesia, telah mengalami perbaikan seperti pertumbuhan ekonomi namun belum diikuti kenaikkan daya saing secara keseluruhan.Pertumbuhan ekonomi Indonesia lebih banyak ditentukan sektor konsumsi, padahal untuk bisa berkelanjutan pertumbuhan harus didasarkan pada kegiatan ekonomi produktif seperti peningkatan investasi dan pertumbuhan eksport.

Saat ini total perdagangan dunia mencapai kurang lebih 5\%, sedangkan tingkat eksport Indonesia hanya mencapai 3\%. Produktifitas manufaktur pada tahun 1993-1997 mencapai $3,47 \%$, saat ini menjadi minus $0,55 \%$ pada periode 1998-2002. Penurunan dratis eksport Indonesia dari sektor manufaktur terjadi pada industri makanan, pakaian jadi, elektronik, tekstil, mesin dan radio televise dan ini semua berpotensi menciptakan gejala deindustrialisasi. Padahal eksport inilah yang bisa diandalkan sebagai pendorong gerak laju pertumbuhan ekonomi apabila iventasi rendah seperti yang dialami oleh Indonesia saat ini.

Berbicara daya saing nasional tidak bisa hanya ditujukan pada suatu produk tanpa mengembangkan sarana pendukungnya. Dengan kata lain daya saing nasional semakin ditentukan oleh kaitan yang kompleks antara kebijaksanaan makro dan industri dengan strategi mikro perusahaan. Usaha membangun daya saing nasional ini demikian mendesak karena kesinambungan pertumbuhan ekonomi kita semakin tergantung pada import di pasar dalam negeri sendiri. Tambahan lagi kesepakatan liberalisasi perdagangan seperti perdagangan bebas ASEAN (AFTA), APEC dan GTT/WTO menghadang di hadapan kita yang seceara nyata menimbulkan dampak buruk bagi masyarakat, keadilan dan lingkungan (Colin Hines, 2000).Dalam komteks Indonesia, kondisi riil masyarakat local saat ini harus diakui sangatlah lemah, terutama secara ekonomis.Itulah sebabnya promosi lokalisme memang tampaknya lebih mendesak daripada sekedar keinginan untuk ikut serta dalam system ekonomi global.Di Indonesia sendiri, banyak sekali industri yang berbasis "padat karya" yang gulung tikar (seperti TPT tekstil dan produk tekstil). Di sektor ini, pasar domestic telah diserbu produk impor yang diindikasikan oleh merosotnya indeks jumlah produksi industri besar dan sedang dari 109,2 pada tahun 2000 menjadi 100,3 di tahun 2002 (Khudori, 2004).

Untuk Kota Ternate, dalam meningkatkan daya saing yang berbasis sumber daya local maka Dinas Perdagangan dan Perindustrian dalam sektor industrinya memberikan pelabelan pada komoditi pangan khususnya home industri makanan khas Maluku Utara seperti Bagea kenari, biskuit kenari, dan macron kenari untuk labelisasi dan tersertifikasi ini di dalam prakteknya mengalami kendala biaya dalam hal pengujian makanan itu sendiri sehat dan hegienis yang harus uji laboratorium dan dilakukan di luar Maluku Utara dan membutuhkan biaya yang cukup tinggi. Padahal dalam labelisasi dan sertifikasi adalah sangat penting di dalam pemasaran produk agar bisa bersaing di daerah, regional dan Internasional untuk dapat bersaing dengan makanan khas daerah lainnya. 


\section{PENUTUP}

\subsection{Kesimpulan}

Industri sebagai penggerak perekonomian rakyat tumbuh dan berkembang sangat tergantung oleh kondisi riil yang ada di setiap daerah masing-masing dimana sangat tergantung oleh unsur-unsur terkait seperti pemerintah, stabilisasi daerah, perbankan dan masyarakatnya itu sendiri.Namun dalam perkembangannya industri itu harus di dorong dan dipacu dari hulu sampai hilir agar perekonomian daerah dapat tumbuh secara berkesinambungan dan akhirnya memberikan kontribusi bagi pertumbuhan ekonomi dan juga dapat membawa dampak dalam pembangunan daerah yang mandiri.

\subsection{Saran}

Beberapa kebijakan yang disarankan untuk melindungi lokalisme antara lain adalah : 1 . Jangan melakukan impor barang dan jasa yang bisa diproduksi sendiri; 2. Menerapkan prinsip produksi untuk konsumsi sendiri (site-here-tosell-here-rules); 3. Mengupayakan agar arus uang tidak banyak keluar dari komunitas lokal (localizing money flows); 4. Mendorong kompetisi local untuk menghasilkan barang dan jasa yang bermutu tinggi; 5.Reorientasi kebijakan perdagangan dengan menitik beratkan pada penguatan ekonomi local daripada membangun daya saing internasional.
Meningkatkan daya saing, merupakan suatu aktivitas yang tidak berjalan sendiri-sendiri tetapi secara lintas sektoral. Beberapa hal yang disarankan dalam penulisan ini adalah :

1. Dalam jangka pendek sebaiknya difokuskan terhadap potensi local yaitu komoditas yang memiliki potensi eksport dan memiliki pangsa pasar yang besar (dominan) di dunia misalnya untuk dengan adanya eksport pala, cengkeh dan komoditas local ungulan yang dimiliki oleh Maluku Utara sendiri. Sehingga diperlukan inventarisasi "positiong" terhadap seluruh komoditas local dibandingkan Negara lain dengan berbagai kekuatan dan kelemahan , hingga segala sesuatu yang menjadi hambatan dapat diketahui dan strategi pengembangannya akan menjadi fokus.

2. Sinergi antara dunia pendidikan, dunia usaha dan pemerintah. Dunia pendidikan juga memberikan peran terhadap kemajuan dunia industri dan daya saingnya. Dunia pendidikan dapat sebagai Litbang serta mencetak tenaga kerja professional yang sesuai dengan kebutuhan industri potensial. Sektor pertanian umpamanya, memerlukan proses industrialisasi yakni dengan mengaplikasikan ilmu pengetahuan dan teknologi ke sektor ini. Demikian ke sektor-sektor lain. Mendorong terhadap pertumbuhan kredit di sektor usaha mikro kecil dan menengah (UMKM).

\section{DAFTAR PUSTAKA}

Bank Indonesia;“ Sistem Informasi Base Line Survey”, hasil penelitian LP3E Fakultas Ekonomi Unpad, 2000

Biro Pusat Statistik; "Statistik dalam angka" 2004

Tulus Tambunan: "Peranan UKM bagi Perekonomian Indonesia". Majalah Usahawan no.07 tahun 2002.

Vita Sarasi; " Strategi pengembangan Bisnis berbasis kualitas produk pada UKM di Jawa Barat", Majalah Usahawan no.04 tahun 2002.

Pemerintah Daerah Kota Ternate Dinas Perdagangan dan Perindustrian; " LaporanTahunan Kerja Dinas Perdagangan dna Perindustrian”, Tahun 2009. 